DOI https:/ /doi.org/10.32837/app.v0i67.1151

УДК 323.212:061.2

\author{
O. B. Cropoba \\ orcid.org/0000-0002-9003-6909 \\ кандидат історичних наук, \\ доиент кафедри історії та політичної теорії \\ Національного технічного університету «Дніпровська політехніка»
}

\title{
ПРОБЛЕМИ ФОРМУВАННЯ НЕУРЯДОВОГО СЕКТОРУ В УКРАЇНІ В УМОВАХ ЄВРОПЕЙСЬКОЇ ІНТЕГРАЦЇ̈
}

Постановка проблеми. Наприкінці 2013 р. громадянське суспільство в Україні чітко визначилося з курсом на європейську інтеграцію, який юридично був закріплений в Угоді про Асоціацію між Україною та Європейським союзом, синхронно ратифікованою Верховною Радою України та ЄС 16 вересня 2014 р. Такий вектор поступу країни зумовив подальший розвиток демократичних інститутів, серед яких чільне місце належить організаціям «третього сектору» або неурядовим організаціям, як їх називають у «Європейській конвенції про визнання юридичними особами міжнародних неурядових організацій» (European Convention, 1986). Високий ступінь сталості цих осередків нерозривно пов'язаний зі сформованою законодавчою базою, власною фінансовою спроможністю, прозорими та дієвими зв' язками з державними установами, бізнес-структурами та суспільством і $є$ важливою ознакою демократичного політичного режиму, що актуалізує потребу їх всебічного вивчення.

Аналіз останніх досліджень і публікацій. Проблематика третього сектору широко вивчається вітчизняними дослідниками в контексті становлення громадянського суспільства в незалежній Україні, і ії відмітною рисою є увага з боку різних суспільних дисциплін: історії, філософії, політології, правознавства тощо, залежно від вибраного аспекту наукового інтересу. До відомих праць можна віднести розвідки Г. Щедрової «Громадянське суспільство і демократична правова держава: проблеми взаємовпливу» (1994), А. Колодій «На шляху до громадянського суспільства. Теоретичні засади й соціокультурні передумови демократичної трансформації в Україні» (2002); В. Моргуна «Суспільно-політичні проблеми розбудови громадського суспільства в незалежній Україні: історичний аспект» (2003), В. Бебика, В. Бортнікова, Л. Дегтярьової «Держава і громадянське суспільство: партнерські комунікації в глобальному світі» (2006). На увагу заслуговують монографія «Громадянське суспільство в сучасній Україні: специфіка становлення, тенденції розвитку» (2006р.), авторами якої є відомі вчені Ф. Рудич, Р. Балабан, Ю. Ганжуров, О. Дергачов, монографія І. Кресіної, О. Скрипника, А. Коваленка «Держава і громадянське суспільство в Україні. Проблеми взаємодії» (2007), книга В. Буряка «Глобальне громадянське суспільство і мережійні революції» (2011), кандидатська дисертація з історії Н. Мороз, присвячена історії становлення громадянського суспільства в Україні у 1991-2010 рр. (2018). У межах досліджень Фонду Демократичних ініціатив ім. Ілька Кучеріва системно аналізує проблематику відомий політолог О. Гарань.

Дослідник А. Кваша зазначає, що дослідження теми часто здійснюється науковцями за певним історичним етапом «громадянського суспільства, який відображає переформатування відносин держави і суспільства іє показником активізації громадськості» (Кваша, 2015, с. 91). Враховуючи усталений методологічний підхід і той факт, що особливістю цієї теми завжди будуть постійно оновлені реалії, що потребуватимуть уваги дослідників, визначимо мету цієї статті - простежити особливості розвитку неурядового сектору в Україні в період проголошення курсу на європейську інтеграцію на державному рівні. Для цього використовуватиметься джерельний матеріал, що міститься у присвячених різним аспектам демократії у світі рейтингових показниках та аналітичних звітах.

Виклад основного матеріалу. Серед найвпливовіших чинників життя країни цього періоду були Євромайдан 2013-2014 рр. та розв'язана проти України у 2014 р. російська агресія. Ці події об'єднали українську націю навколо ідеї захисту суверенітету держави та європейських 
цінностей, серед яких - і розвинене громадянське суспільство. Підтвердження його оновленої ролі на згаданому етапі міститься у словах професора О. Гараня, який зазначив, що «після Свромайдану громадянське суспільство намагається реально контролювати владу» (Гарань, 2018).

Дійсно, в третьому секторі зосереджуються найактивніші громадяни, які виступають із пропозиціями законопроектів та ініціатив, координуючи свою діяльність із владними структурами. У 2014 р. команда ініціативної групи «Реанімаційного пакету реформ», до якої входили й експерти громадських організацій, підготувала «Дорожню карту реформ» на 2015 рік, спонукаючи уряд і парламент проводити зміни у 18 найважливіших галузях. Задіяні в роботі громадські активісти, експерти та журналісти взяли участь у розробці 119 законів, 60 з яких були прийняті парламентом вже у 2015 р. (2015 CSOSI, 2016, с. 244). Ще одним підтвердженням злагодженої роботи владних органів і громадського сектору стала можливість виконати «144 висунені Свропейським Союзом вимоги для надання Україні безвізового режиму», який вступив у силу з 11 червня 2017 р. (Про стан розвитку, 2017, с. 6).

За даними Індексу сталості організацій громадянського суспільства (CSOSI), загальна сталість в Україні протягом 2014-2018 рр. залишалася незмінною, щорічно дорівнюючи 3.3 бала, за винятком 2017 р., коли показники трохи покращилися, досягнувши оцінки 3.2 бала (2014 CSOSI, 2015, C.235; 2015 CSOSI, 2016, C. 244; 2016 CSOSI, 2017, C. 240; 2017 CSOSI, 2018, C. 219; 2018 CSOSI, 2019, С. 229). Однак у межах загальної стабільності в окремих категоріях індексу спостерігалися коливання в той чи інший бік.

У сукупності оцінок щодо стану третього сектору цього періоду існує широко розповсюджена думка про погіршення показників розвитку неурядових організацій через внесені в березні 2017 р. до Закону України «Про запобігання корупції» зобов' язання для членів антикорупційних громадських організацій подавати електронні декларації та спроби парламенту ввести додаткову звітність для неурядових організацій, що отримують іноземне фінансування (2018 CSOSI, 2019, С. 229; Про стан розвитку, 2017, С. 49). Погіршення ситуації також пов'язують зі збільшенням у 2017 р. фізичних нападів на громадських активістів. Проте за рахунок вдосконалення фінансової спроможності неурядових організацій, які почали залучати ресурси як державного, так і приватного секторів, показник загальної сталості 2018 р. був стабільним, не виходячи за межі тенденції 2014-2018 рр.

У добу кристалізації суспільної потреби в проєвропейському шляху розвитку в країні стрімко зростає розуміння ролі неурядових організацій у справі демократичних трансформацій. На тлі розпочатого широкомасштабного реформування зміни відбуваються і у сфері правового регулювання самого громадського сектору, що показано в характеристиці категоpiї «правове середовище» Індексів CSOSI.

Прийнятий ще 14 жовтня 2014 р. Закон України «Про запобігання корупції» надав можливості громадським об'єднанням здійснювати антикорупційні заходи та брати участь у відборі членів Національного агентства із запобігання корупції, що зазначено в Розділі II, статті 14 (Закон України «Про запобігання корупції», 2014). Інший документ, Закон 475-VIII 2015 р., спростив процедуру заснування громадських асоціацій, зменшивши термін їх реєстрації до 3 днів і зробивши ї̈ безкоштовною (2015 CSOSI, 2016, с. 245). Закладено підгрунтя для регулювання роботи волонтерів, у тому числі й пов'язаних із зоною АТО, про що свідчить створення Ради з координації роботи щодо надання волонтерської та благодійної допомоги при Міністерстві соціальної політики України (Положення про Раду, 2015). Розуміння значущості третього сектору втілилося й в Указі Президента від 26 лютого 2016 р. «Про затвердження Національної стратегії сприяння розвитку громадянського суспільства в Україні на 20162020 роки» (Національна стратегія, 2016). За даними Програми розвитку Об'єднаних Націй, уже в 2018 р. в Україні було впроваджено 70\% заходів, передбачених цією стратегією (2018 CSOSI, 2019, C. 230).

Помітний вплив на характеристики категорії «організаційна спроможність» третього сектору також мала суспільна згуртованість навколо потреби відстояти суверенітет держави та євроінтеграційний вектор. За цих умов соціальна база громадського сектору збільшується за рахунок представників середнього класу - викладачів, медиків, фахівців із комп'ютерних технологій, підприємців тощо, які майже в кожному місті країни об'єднуються з метою допомог- 
ти армії та переселенцям. Розбудові організаційних потужностей українських громадських організацій допомагають і міжнародні партнери, в основному урядові структури і фонди розвинених країн, які працюють над поширенням демократичних цінностей у світі. Вітчизняні неурядові організації відчувають незмінну підтримку від Агенції з міжнародного розвитку США (USAID), Швецької агенції з міжнародного співробітництва (Sida), Британського департаменту міжнародного розвитку та інших партнерів (2015 CSOSI, 2016, C. 247).

Серед вагомих ініціатив підтримки неурядового сектору є Програма «Engage» («Долучайся»), яка сприяє розбудові ресурсних установ, включаючи 15 вузлових громадських центрів, створених у межах Програми розвитку Об'єднаних націй (UNDP), що взаємодіють з ініціативними групами на місцевому рівні. Ресурсні центри також підтримуються місцевою владою. До того ж послуги для своїх учасників надаються і Форумом неурядових організацій (НУО), а Міністерство молоді та спорту підтримує молодіжні центри, які надають послуги структурам, орієнтованим на молодь (2018 CSOSI, 2019, с. 236).

У досліджуваний період спостерігається тенденція збільшення кількості неурядових організацій. Так, якщо станом на 1 січня 2016 р. в Україні налічувалось 70,321 громадських асоціацій, 15,384 благодійних організацій, 279 творчих спілок, то станом на 1 січня 2019 р. тут вже було 84,608 громадських асоціацій, 28,026 профспілок, 314 творчих спілок, 18,433 благодійних організацій (Єгорова, 2020, С. 126).

ндекс CSOSI за 2018 р. відзначає нерівномірний розподіл потужностей серед організацій різних регіонів країни. 3 одного боку, сформувалися розвинені осередки у Львівській, Дніпропетровській, Харківській та Одеській областях, тоді як на Закарпатті, у Хмельницькій, Волинській, Чернівецькій та Сумській областях можливості організацій набагато менші (2018 CSOSI, 2019, с. 231). Натомість діяльність усіх осередків характеризується зміцненням зв'язків із зацікавленими громадянами, розвитком ресурсів у соціальних мережах, веб-сайтів та інших засобів ефективної взаємодії зі своєю цільовою аудиторією.

Допомога Україні в розбудові демократичних інститутів з боку західних партнерів сприяє й покращенню категорії «фінансової стійкості» неурядових організацій. Підтримка міжнародних донорів здебільшого спрямована на внутрішньо переміщених осіб та угамування конфлікту на Сході. За даними Ініціативного центру сприяння активності та розвитку громадського почину «Еднання», у 2015 р. понад 70\% фінансування нових ініціатив НУО було спрямовано на внутрішньо переміщених осіб (2015 CSOSI, 2016, с. 248).

На 2015 р. припадає і пік активності самих українців у допомозі родинам загиблих під час протестів на Євромайдані, волонтерам та військовим, що захищають східні рубежі країни. Всесвітній індекс благодійності за 2015 р. показав кардинальне збільшення внесків наших співгромадян у благодійництво: у 2014 р. позитивну відповідь дали 38\% респондентів, порівняно 3 9\% у 2013 р. (2015 CSOSI, 2016, С. 249).

Зростання громадянської підтримки компенсує скорочення монетарних надходжень і пожертвувань у натуральній формі з боку місцевих бюджетів, яке спостерігалося у 2015 р. Для привертання уваги громадськості неурядові організації винаходять більш різноманітні методи збору пожертвувань, залучаючи онлайн-платформи. Водночас дедалі частіше авторитетні осередки, фіксуючи незадовільний стан свого фінансового менеджменту, приходять до розуміння необхідності професійних тренінгів із менеджменту та бухгалтерської справи.

У наступні роки збільшення фінансової спроможності неурядових організацій уможливлюється завдяки розширенню доступу до ресурсів 3 державного та приватного секторів. Відповідно до даних Державної служби статистики, у 2016 р. 23,237 асоціацій показали дохід \$258.9 млн, тоді як у 2017 р. 25,988 громадських асоціацій задекларували \$269.3 млн прибутку. Джерела прибутку включали державний і місцевий бюджети, членські внески, благодійні пожертвування, економічну діяльність та інші джерела (2018 CSOSI, 2019, с. 233). У 2018 р. Miністерство соціальної політики, Міністерство молоді та спорту та Міністерство культури загалом виділили на громадські організації 13,6 млн дол. США, що в 1.7 раза більше, ніж у 2017 і 2016 рр. (Сгорова О.В., 2020, с. 126).

Водночас неурядові організації працюють над удосконаленням змісту своєї роботи, що відображується в категорії «адвокації». Масштабні адвокаційні кампанії громадських активіс- 
тів пов'язані із законотворчістю в найактуальніших питаннях на національному і місцевому рівнях, для чого налагоджується тісна співпраця з урядовими інститутами. Важлива частина роботи реалізована в багатосторонній міжнародній ініціативі «Відкритий уряд» та партнерстві «Відкритий парламент», до якого Україна приєдналася 5 лютого 2016 р., підписавши Декларацію відкритості парламенту. Напрями діяльності включали сприяння участі інститутів громадянського суспільства у формуванні та реалізації державної політики у запобіганні та протидії корупції і забезпеченні доступу до публічної інформації. За участі громадськості були розроблені і прийняті Закон України «Про внесення змін до деяких законодавчих актів України щодо забезпечення прозорості у видобувних галузях» (від 16 червня 2015 р.), «Національна Стратегія у сфері прав людини» (25 серпня 2015 р.) та інші документи.

Протягом наступних років НУО виконували значний обсяг робіт із впорядкування реформ у країні, працюючи над антикорупційними ініціативами, юридичними питаннями, проблемами національної безпеки, проведенням пенсійної реформи, виборчої реформи, децентралізації, а також питаннями судочинства, освіти й охорони здоров'я.

3 огляду на особливості суспільно-політичної ситуації в країні, набуває значущості ще одна характеристика діяльності громадянського суспільства, втілена в категорії «надання послуг». У цей час базовий спектр послуг третього сектору зосереджений на допомозі Українській армії, людям із зони збройного конфлікту, внутрішньо переміщеним особам із Криму та Сходу України, ветеранам, людям з обмеженими можливостями. Загальний перелік видів допомоги включає тренінги, консультування, інформаційні послуги, базові соціальні послуги для молоді, людей старшого віку, надання їжі та притулку, інформацію з реєстрації, допомогу в працевлаштуванні та психологічній підтримці. Часто неурядові осередки виступають з' єднувальною ланкою між переміщеними особами та місцевою громадою, знижуючи напругу складної ситуації (2015 CSOSI, 2016, с. 251).

Водночас НУО виходять на якісно новий рівень роботи, беручи участь у соціальних контрактах та державних закупівлях. Урядові структури купують послуги у третього сектору на національному і місцевому рівнях. Однак це ще не стало дуже розповсюдженою практикою. Хоча Міністерство соціальної політики й розробило відповідні стандарти взаємин, але в аналітичному огляді цього питання з Індексу CSOSI наголошено, що державним інституціям потрібно більше тренінгів щодо закупівлі соціальних послуг у громадських організацій (2018 CSOSI, 2019, с. 235).

В українських реаліях діяльність неурядових організацій все більше знаходить підтримку громадян, які допомагають їм зусиллями і фінансами, що дозволяє Індексу CSOSI визначити категорію «публічного іміджу» неурядового сектору. ЗМІ висвітлюють його роль у просуванні демократичних реформ, боротьби з корупцією, а також у допомозі сім'ям загиблих, воїнам ATO, переміщеним особам з Криму і Донбасу. Відтоді невід'ємною частиною новинних програм і ток-шоу стають виступи громадських активістів. Згідно з проведеним 2018 р. програмою «Долучайся» анкетуванням, за останній рік довіра до громадських організацій зросла. Наприклад, 60\% респондентів довіряють волонтерським групам, а 45\% - громадським організаціям, порівняно з відповідними показниками 53\% і 40\% у 2017 р. I хоча урядові установи не завжди бачать їх продуктивними партнерами, але суспільство сприймає неурядовий сектор як альтернативу державним політичним інститутам, віддаючи належне його системній і результативній роботі. 3 опитування, проведеного у 2018 р. Фондом «Демократичні ініціативи», до головних рушійних сил змін суспільство відносить власне громадські організації та західних партнерів (2018 CSOSI, 2019, с. .234).

До наданого аналізу варто додати і тенденцію роботи третього сектору над покращенням власної прозорості завдяки публікаціям щорічних звітів на своїх веб-сайтах. У 2018 р. вдвічі більше організацій, включаючи НУО з регіонів, приєдналися до започаткованого Програмою розвитку Об'єднаних націй змагання на кращі звіти серед громадських організацій, порівняно $з 2017$ р. (2018 CSOSI, 2019, C.237).

Висновки. Таким чином, у період слідування Україною оголошеним на державному рівні курсом на європейську інтеграцію відбуваються якісні зміни в роботі неурядових організацій і їх кількісне зростання. В цей час наявна тенденція загальної стабільності третього сек- 
тору. Удосконалюється правове регулювання його діяльності, що проявляється у створенні необхідних правових засад для сприяння розвитку громадських установ - офіційному закріпленню їх участі в роботі державних антикорупційних органів, спрощених процедурах реєстрації, запровадженні національної стратегії підтримки. Громадські активісти долучаються до системного реформування країни, працюючи з урядовими інституціями в актуальних сферах над розробленням і впровадженням антикорупційного законодавства, допомогою Українській армії та внутрішньо переміщеним особам. Разом із тим неурядові організації стикаються 3 проблемами, пов'язаними з недостатніми ресурсними можливостями окремих осередків, збільшенням кількості нападів на громадських активістів та спробами держави ввести додаткову звітність. Однак загалом позитивні тенденції в розвитку неурядового сектору помітно переважають. Організації покращують свій інституційний потенціал та систему управління, збільшують фінансові можливості, що відбувається за рахунок диверсифікації джерельної бази доходів. Стабільно високою залишається суспільна підтримка волонтерських організацій, націлених на допомогу українським військовим, захист проєвропейського курсу та демократичні реформи в державі.

\section{Лimepamypa}

Гарань О. [Громадянське суспільство тягне Україну вгору]: інтерв'ю 27.01.18p. URL : https:/ dif.org.ua/ article/gromadyanske-suspilstvo-tyagne-ukrainu-vgoru-garan (дата звернення: 10.03.2021).

Єгорова О.В. До характеристики джерельної бази дослідження стану громадянського суспільства в Україні. Проблеми формування громадянського суспільства в Україні: виклики та колізї̈: матеріали Всеукр. наук.-практ. конф., 15 трав. 2020 р. Дніпро : ДДУВС, 2020. С. 124-128.

Кваша А.С. Розвиток громадянського суспільства в Україні та проблеми об'єктивності його дослідження. Ефективність державного управління. 2015. Вип. 44(1). С. 91-97.

Положення про Раду з координації роботи щодо надання волонтерської та благодійної допомоги при Міністерстві соціальної політики України : Наказ Міністерства Соціальної політики України від 18.05.2015 p. № 516 URL: https:/ /zakon.rada.gov.ua/laws/show/z0649-15\# (дата звернення: 20.08.2020).

Про запобігання корупщії : Закон України від 14.10.2014 p. № 1700-VII. Відомості Верховної Ради України. 2014. №49.Розд.II. Ст. 14.

Про стан розвитку громадянського суспільства в Україні : аналіт. доповідь / за заг. ред. О. А. Корнієвського. Київ : НІСД, 2017. 56 с.

Указ Президента України про «Національну стратегію сприяння розвитку громадянського суспільства в Україні на 2016-2020 роки» від 26.02.2016 р. № 68/2016 URL: https://zakon.rada.gov.ua/laws/ show/68/2016\#Text (дата звернення: 03.03.2021).

2014 CSOSI. URL: https://www.usaid.gov/sites/default/files/documents/1863/EuropeEurasia_FY2014_ CSOSI_Report.pdf (дата звернення: 20.08.2020).

2015 CSOSI. URL: https://www.usaid.gov/sites/default/files/documents/1861/Europe_Eurasia CSOSIReport_2015_Update8-29-16.pdf (дата звернення: 20.08.2020).

2016 CSOSI. URL: https://www.usaid.gov/sites/default/files/documents/1866/CSOSI_Report_7-28-17.pdf (дата звернення: 20.08.2020).

2017 CSOSI. URL: https://www.fhi360.org/sites/default/files/media/documents/resource-csosi-2017report-europe-eurasia.pdf (дата звернення: 20.08.2020).

2018 CSOSI. URL: https://www.fhi360.org/sites/default/files/media/documents/resource-csosi-2018report-europe-eurasia.pdf (дата звернення: 20.08.2020).

European Convention on the Recognition of the Legal Personality of International Non-Governmental Organisations, 1986. URL: https://www.coe.int/en/web/conventions/full-list/-/conventions/ rms/090000168007a67c (дата звернення: 10.08.2020).

\section{References}

Garan', O. (2018). Gromadianske suspilstvo tiagne Ukrainu v goru. [Civil Society is pulling Ukraine upwards]. Retrieved from https://dif.org.ua/article/gromadyanske-suspilstvo-tyagne-ukrainu-vgoru-garan. [in Ukrainian].

Yehorova O.V. (2020). Do kharakterystyky dzherelnoi bazy doslidzhennia stany gromadianskoho suspilstva $\mathrm{v}$ Ukraini. [To the characteristics of source basis of researching the state of civil society in Ukraine]. Abstract of papers '20: Problemy formuvannia gromadianskogo suspilstva v Ukraini: vyklyky ta kolizii. (pp. 124-128). Dnipro. [in Ukrainian]. 
Kvasha A.S. (2015). Rozvytok gromadianskogo suspilstva v Ukraini ta problemy objectyvnosti yogo doslidzhennia. [Development of Civil Society in Ukraine and issues of its research objectivity]. Efectyonist derzhavnogo upravlinnia - Effectiveness of Public Administration, 44(1), 91-97. [in Ukrainian].

Polozhennia pro Radu z koordinatsii roboty shchodo nadannia volonterskoi ta blagodiinoi dopomogy pry Ministerstvi sotsialnoi polityky Ukrainy : Nakaz Ministerstva Sotsialnoi polityky Ukrainy. [Statement about the Counsel on coordination of work in providing volunteer and charity assistance at the Ministry of Social Policy of Ukraine] (2015). Retrieved from https:/ / zakon.rada.gov.ua/laws/show/z0649-15\#. [in Ukrainian]. Pro zapobigannia koruptsii : Zakon Ukrainy vid 14.10.2014 № 1700-VII. [Law of Ukraine “On Prevention of Corruption"]. (2014). Vidomosti Verkhovnoi Rady Ukrainy - News of Verkhovna Rada of Ukraine, \#49. [in Ukrainian]. Korniyevski, O.A. (Ed). (2017). Pro stan rozvytku gromadianskogo suspilstva v Ukraini : analitychna dopovid [About the civil society development state in Ukraine : analytical report]. Kyiv: NISD. [in Ukrainian].

Ukaz Presidenta Ukrainy "Pro Natsionalnu strategiyu spryiannia rozvytku gromadianskogo suspilstva v Ukraini na 2016-2020 roky". [Decree of the President of Ukraine "National strategy of fostering the development of Civil Society in Ukraine for 2016-2020"] (2016). Retrieved from https:/ / zakon.rada.gov.ua/ laws/show/68/2016\#Text. [in Ukrainian].

2014 CSOSI. Retrieved from https://www.usaid.gov/sites/default/files/documents/1863/EuropeEurasia_ FY2014_CSOSI_Report.pdf.

2015 CSOSI. Retrieved from https://www.usaid.gov/sites/default/files/documents/1861/Europe_Eurasia_ CSOSIReport_2015_Update8-29-16.pdf.

2016 CSOSI. Retrieved from https://www.usaid.gov/sites/default/files/documents/1866/CSOSI_ Report_7-28-17.pdf.

2017 CSOSI. Retrieved from https://www.fhi360.org/sites/default/files/media/documents/resource-csosi2017-report-europe-eurasia.pdf.

2018 CSOSI. Retrieved from https://www.fhi360.org/sites/default/files/media/documents/resource-csosi2018-report-europe-eurasia.pdf.

European Convention on the Recognition of the Legal Personality of International Non-Governmental Organisations, 1986. Retrieved from https://www.coe.int/en/web/conventions/full-list/-/conventions/ rms/090000168007a67c.

\section{Анотація}

Єгороља О. В. Проблеми формування неурядового сектору в Україні в умовах європейської інтеграції. - Стаття.

У статті розглянуто особливості розвитку неурядового сектору в Україні в період проголошення на державному рівні курсу на європейську інтеграцію. 3'ясовано, що в цей час відбуваються якісні зміни в роботі неурядових організацій і їх кількісне зростання. В окремих областях сформовані розвинені осередки. Наявна тенденція загальної стабільності третього сектору в країні. Зазначено, що удосконалюється правове регулювання його діяльності, що проявляється у формуванні необхідних правових засад для сприяння розвитку громадських установ - офіційному закріпленню їх участі в роботі державних антикорупційних органів, спрощених процедурах реєстрації, запровадженні національної стратегії підтримки. Громадські активісти долучаються до системного реформування країни, працюючи з урядовими інституціями в актуальних сферах над розробленням і впровадженням антикорупційного законодавства, допомогою Українській армії та внутрішньо переміщеним особам.

Соціальна база громадського сектору збільшується за рахунок представників середнього класу. Зазначено, що розбудові організаційних потужностей українських громадських організацій допомагають і міжнародні партнери. Проте показано, що для розвитку неурядових організацій притаманні проблеми, пов'язані з недостатніми ресурсними можливостями в окремих областях України, збільшенням кількості нападів на громадських активістів, а також спробами держави ввести для членів організацій додаткову звітність.

Водночас доведено, що загалом організації покращують свій інституційний потенціал та систему управління, збільшують фінансові можливості, що відбувається за рахунок диверсифікації джерельної бази доходів. Стабільно високою залишається суспільна підтримка волонтерських організацій, націлених на допомогу українським військовим, захист проєвропейського курсу та кореляцію з цією стратегією демократичних реформ у Державі.

Ключові слова: громадянське суспільство, неурядові організації, волонтерські організації, європейська інтеграція. 


\section{Summary}

Yehorova $O$. $V$. Issues of non-governmental sector formation in Ukraine under the conditions of European integration. - Article.

In the article the peculiarities of non-governmental sector development in Ukraine during the period of declaring the European integration course on a governmental level are considered. It's found out that qualitative changes in the non-governmental organizations' work and their quantitative growth are going on at the moment.

In certain Regions powerful entities have been established. There is a clear trend of the third sector's general stability in the country. The law regulation of the NGOs' activity is being improved, which is seen in the proper law bases for fostering the development of public entities. Their participation in the work of state anti-corruption structures has been allowed. Simpler procedures of registration and national strategies of support have been implemented.

It has been approved that civil activists are being engaged in systematic reforming of the country. They are working together with governmental offices in important areas over the development and implementation of anti-corruption laws, helping Ukrainian Army and internally displaced people.

The social basis of the civil sector is being increased on account of middle-class representatives. It's marked that international partners provide a strong support in developing organizational capacities of NGOs. At the same time it's shown that certain faults are peculiar for the sector. The issues are linked with poor resource capacities in some regions of Ukraine, assaults on civil activists, as well as state authorities' attempts to implement extra reports for the members of civil organizations.

Nevertheless, it has been concluded that as a whole the organizations are improving their institutional capacities and management, increasing financial opportunities by means of diversifying the income resource basis. The public support to the volunteer organizations aimed at helping Ukrainian military and defending Ukrainian pro-European course and carrying out democratic reforms in the state is remaining steadily high.

Key words: civil society, NGOs, volunteer organizations, European integration. 